\title{
Towards improving the performance of flexible manufacturing system: a case study
}

\author{
Ajay Singholi ${ }^{1}$, Deepti Chhabra ${ }^{1}$, Mohammad $\mathrm{Ali}^{2}$ \\ ${ }^{1}$ Guru Gobind Singh Indraprastha University (INDIA); ${ }^{2}$ Aligarh Muslim University (INDIA) \\ ajay.igit@gmail.com;mohdali234@,rediffmail.com;deepti2226@,yahoo.co.in
}

Received October 2009

Accepted April 2010

\begin{abstract}
Increasing global competition has evolved a manufacturing environment which gleans vast product variety, reduced manufacturing lead times, increased quality standards and competitive costs. Simultaneously, with a rising trend toward globalization, these manufacturing environments must be designed to cater new challenges to survive and grow in the marketplace. To deal with such multifaceted problems, new technologies support increased flexibility and automation. These objectives intended for the improvement of the manufacturing environment have been the key rationales for the introduction of flexible manufacturing systems (FMSs). In this paper a case study of a firm is presented with a contribution to suggest some methods of performance improvement for a flexible system of manufacturing. The study is based on the mathematical models illustrated in literature to estimate possible performance parameters like maximum production rate, make span time and overall utilization. Through this study, an effort is also made to present the improved design for existing flexible manufacturing system employed in the company. Various design and performance parameters are then evaluated and compared for the existing and improved FMS.
\end{abstract}

Keywords: flexible manufacturing system, performance parameters, production rate, makespan time 


\section{Introduction}

Competitive business environment offers new pressures to be confronted by the manufacturing systems, such as tailored product (increasing variety) with delivery on time along with emphasize conventional requirements of quality and competitive cost. Therefore, to sustain in the global scenario, the focus is to develop a manufacturing system that can fulfil all the demanded requirements within due dates at a reasonable cost. The introduction of Flexible manufacturing System (FMS) facilitates manufacturing industries to improve their performance along with the flexibility to make the customized product with medium volume. A Flexible manufacturing System (FMS) can be defined as a computer-controlled configuration of semi-dependent workstations and material-handling systems designed to efficiently manufacture various part types with low to medium volume. It combines high levels of flexibility with high productivity and low level of work- in-process inventory (J ang \& Park, 1996). The exquisiteness of FMS is that it gleaned the ideas both from the flow shop and batch shop manufacturing system and is designed to imitate the flexibility of job shops while maintaining the effectiveness of dedicated production systems. Such FMS should be designed to improve productivity while fulfilling the demand with decreasing makespan time. A generic FMS is able to handle a variety of products in small to medium sized batches simultaneously. The flexibility of a flexible manufacturing system (FMS) has enabled it to become one of the most suitable manufacturing systems in the current manufacturing scenario of customized and varied products with shorter life cycles.

With the aim of combining production flexibility and productivity, the design of flexible manufacturing system (FMS) is subject of high investments. Deterministic models based on discrete-event simulation can be utilized to design production systems such as FMSs. Distinctively these are used to design and size the hardware requirements of a FMS (buffer capacity, layout design, material handling layout design, and number of workstations with respect to the projected production) with an objective to raise the utilization of resources. However these decisions of FMS design are strategic and to be taken in initial phase with extreme care ensuring that the designed FMS will successfully fulfill the demands of fluctuating market. The design decisions of FMS must be based on the justification of performance improvement. In recent environment where a manager can make use of easily available computing power along with the various commercial tools and techniques, 
it is quite reasonable to estimate some performance issues of existing and proposed FMS and subsequently suggest the design decisions. The employment of above mentioned tools and models to judge the FMS performance could be very useful to evaluate the system parameters like production rate, resource utilization, make span time etc. at a beginning stage of design decision making. The company selected for the case was under pressure from the market and was ready with the funds to introduce some major modifications in their existing system to improve the productivity along with the flexibility to survive in the competitive working domain.

This paper presents a study performed for performance evaluation of an existing system with the objective to improve the performance by designing a new FMS. The case company is located in National Capital Region of India and was striving to improve the performance of existing flexible system and setting up to make some investment decisions for up-gradation.

The remainder of this paper is described as following: Section 2 gives an overview of the literature surveyed to conduct the research; subsequently section 3 delineates the problem definition along with the objectives of the case and the data collection. Section 4 includes the design and simulation of new FMS while section 5 analyses and compares the results of the study. In section 6 , the paper has been concluded with some issues and future intensions of the research.

\section{Literature review}

The framework of flexible manufacturing systems (FMSs) combines high productivity, quality and flexibility needed for the fast response to changing market demands (Womack, Jones \& Roos, 1990). The term flexible manufacturing system (FMS) is generally used to represent a wide variety of automated manufacturing systems. Flexible Manufacturing System (FMS) can be defined as an integrated system composed of automated workstations such as computer numerically controlled (CNC) machines with tool changing capability, a hardware handling and storage system and a computer control system which controls the operations of the whole system (Mac Carthy, 1993). Tempelemeier \& Kuhn (1993) define FMS as a production system consisting of a set of identical and/or complementary numerically controlled machines, which are connected through an automated transportation system. Each process in an FMS is controlled by a dedicated 
computer (FMS cell computer). As per Parrish (1990), a flexible manufacturing system is a collection of production equipment logically organized under a host computer and physically connected by a central support system. The main impetus to switch from a traditional system to an FMS is to introduce flexibility in manufacturing operations so that a firm can compete more efficiently in the marketplace. Suresh and Sridharan (2007) described FMS as a growing technology mainly suitable for mid-volume, mid-variety production, they also defined FMS as an integrated production facility consisting of multifunctional numerically controlled machining centers connected with an automated material handling system, all controlled by a centralized computer system. An FMS is designed to have capability of concurrently handling a range of product types in batches (small to medium sized) and at a high efficiency as compared to that of traditional production systems which are designed to deal with low-variety parts in high volume. This system is able to process any part that belongs to specific families within the prescribed capacity according to a predetermined schedule. Generally, the system is designed in such a way that manual interference and change over time are minimized (Chan \& Chan, 2004). One of the objectives of an FMS is to achieve the flexibility of small volume production while maintaining the effectiveness of largevolume mass production. The flexibility of a flexible manufacturing system (FMS) has enabled it to become one of the most suitable manufacturing systems in the current manufacturing scenario of customized and varied products with shorter life cycles. Ramasesh and Jaykumar (1991) stated that manufacturing flexibility can be of several different forms e.g. machine, operation, material handling, routing, program, expansion, process, product, volume, labor and material flexibilities. Sethi and Sethi (1990) gave the concept of eleven flexibility types, Browne et.al. (1984) illustrated only eight types, which are known as; machine flexibility, process flexibility, routing flexibility, operation flexibility, product flexibility, volume flexibility, part mix flexibility and production flexibility. An FMS can provide one or more of the above flexibilities. The consideration of a particular type of flexibility to be considered in the design of an FMS depends upon the system objectives. The increase in flexibility provides the alternative resources/machines to do the same processing (Shnits et al., 2004). However, the flexibility and effectiveness of an FMS is restricted by the availability of equipment. The effectiveness of any FMS is generally described as being its ability to deal with the changes in the nature, mix, volume or timing of its activity. This ability is usually compressed into the term 
'flexibility' or more comprehensively an ability to cope with the uncertainty of changes (Correa \& Slack, 1996; Barad \& Sipper, 1988). An appropriate preplanning is essential for FMS success to enhance the efficiency, flexibility, and utilization of resources and to decrease setup costs. The prominent literature has several descriptions of FMS and its inherent feature of flexibility has been addressed by many researchers (Browne et al., 1984; Upton, 1994; Wadhwa and Browne, 1989). The flexibility of an FMS is used to enhance versatility of the system and therefore the right type of flexibility is required to be implemented in the system. The case considered for the study is designed for some of the most basic flexibility types such as routing flexibility and volume flexibility. These flexibility types are very much required to make the system more responsive towards the machine failure (routing flexibility) and unexpected increase in demand (volume flexibility).

To design an efficient flexible manufacturing system, an information system is incorporated to interface and integrate the entities of FMS, the mode of synchronizing the various entities and the method of coordinating them in order to achieve the objectives (Weber \& Moodie, 1989). Buitenhik et al. (2002) describe that the components of an FMS are generally expensive therefore the design of these systems is an important issue. Stecke and Solberg (1981) report on an experimental examination of a real FMS. The system consists of 9 machining centers, an inspection station and a control queuing area connected by an automated material handling system. The number of finished parts was considered as the system performance measure. In recent studies pertaining to the FMS, researchers have been very keen to improve the performance of flexible manufacturing system (Wadhwa et al., 2005; Chan, 2003). Some researchers have used deterministic models to estimate the FMS performance; these models are very useful for estimating system parameters such as production rate and resource utilization at a beginning stage of design. Solberg (1981) and Mejabi (1988) presented a universally accepted mathematical model (deterministic in nature) to evaluate various performance measures of an FMS. Montazeri and Van Wassenhove (1990) investigated the performance of a number of dispatching rules for FMS. Chan, Wadhwa and Bibhushan, (2007) initiate an idea to extend the performance analysis to FMS related technologies such as supply chains. It is found in literature that performance improvement studies often involve the use of simulation experiments. Ali and Wadhwa (2005) performed simulation experiments to evaluate 
the effect of various flexibility types and control rules on the performance of FMS. Simulation modeling has been broadly proposed by the researchers for the analysis of complex systems. It provides a simple platform to model the variables that are complicated to model mathematically or which involves improbable assumptions. Therefore, simulation is suitable for representing a complex system to get a feeling for the real system. It may be especially true for FMSs with a heterogeneous and dynamic environment where on-line control strategies with respect to time are employed (Chan \& Chan, 2004). Tunali (1997) developed a simulation model of a job shop type FMS. The model was used to investigate how the performance of scheduling decisions (i.e. mean job flow time) is affected by the use of flexible or prefixed part process plans, in case of a machine breakdown situation. To deal with the operational problems of flexible manufacturing systems such as routing and scheduling, simulation modeling has proved to be practical. Many researchers used simulation to study the scheduling and routing decisions for FMS.

In general, there are two types of problem that need to be addressed in an FMS, namely design problems and operational problems (Kusiak, 1985). The former deals with selection of FMS components while the latter concerns the utilization aspects of FMSs. This paper focuses on both aspects of FMS problems, first the operational study of existing FMS has been performed using mathematical models available in literature, and secondly a new FMS has been designed and simulated to depict the proposed performance improvement plans of the firm. The case considered in this paper requires contribution in terms of introduction of performance improvement strategies to the firm. A simulation model has also been developed to design and estimate the performance measures of new FMS and simultaneously it identifies the machine or load/unload station as bottleneck point in the FMS. The effort is also made to suggest some improvement strategies to the company as a feedback statement which results in higher production rate and better utilization of system resources.

\section{Description of case company and problem definition}

The Case Company is located in National Capital Region of India and specialized in the production of various types of valves (e.g. dual plate check valve, concentric butterfly valve, etc.) of large sizes and pressure ratings for the use in general fire safe and cryogenic applications whereas the material for these products ranging 
from the basic steels, superior alloys to titanium. The company is emerging and has become established among top five quality manufacturers internationally in this range with the certifications like CE, ISO \& API 6D. The company's world class manufacturing base spans over more than 100000 square feet area equipped with modern machining centers, large size material processing and material handling equipment. The company is forward looking and has been investing in to infrastructure and $R \& D$ very regularly, thus giving better scope for the study and analysis. The study intends to conduct a performance analysis of the existing flexible system of manufacturing using the modeling technique mentioned above. The analysis leads us to predict the strategies for the improvements in performance parameters of the system.

The study has been done by following a standard research methodology, a questionnaire was designed and circulated among various levels of people in the company and thus the data was formulated. The FMS is involved in manufacturing of four part types, dual plat check valve, concentric butterfly valve, double eccentric butterfly valve and triple eccentric butterfly valve. The FMS has been studied as a standard case of job shop type manufacturing. The design details and production processes along with the times are discussed below:

\subsection{Dual plate check valve}

\begin{tabular}{|c|c|c|c|c|c|c|c|c|c|c|c|}
\hline \multirow{2}{*}{$\begin{array}{c}\text { Part } \\
\text { Range } \\
(\mathbf{m m})\end{array}$} & \multirow{2}{*}{$\begin{array}{c}\text { Part } \\
\text { Mix }\end{array}$} & \multicolumn{10}{|c|}{ Total Processing Time (Min) } \\
\cline { 3 - 12 } & $\begin{array}{c}\text { Load/ } \\
\text { Unload }\end{array}$ & $\begin{array}{c}\text { Tur- } \\
\text { ning }\end{array}$ & $\begin{array}{c}\text { Wel- } \\
\text { ding }\end{array}$ & $\begin{array}{c}\text { Dril- } \\
\text { ling }\end{array}$ & $\begin{array}{c}\text { Mil- } \\
\text { ling }\end{array}$ & $\begin{array}{c}\text { Surface } \\
\text { Grinding }\end{array}$ & $\begin{array}{c}\text { Lap- } \\
\text { ping }\end{array}$ & Insp & $\begin{array}{c}\text { Pain- } \\
\text { ting }\end{array}$ & $\begin{array}{c}\text { As- } \\
\text { sly }\end{array}$ \\
\hline 40 & 0.0004 & 20 & 60 & 25 & 12 & 10 & 30 & 90 & 25 & 10 & 30 \\
\hline 50 & 0.0247 & 20 & 75 & 30 & 15 & 15 & 45 & 120 & 30 & 10 & 30 \\
\hline 65 & 0.0227 & 20 & 90 & 40 & 20 & 20 & 60 & 156 & 30 & 10 & 30 \\
\hline 80 & 0.03 & 20 & 120 & 50 & 25 & 25 & 75 & 192 & 30 & 15 & 30 \\
\hline 100 & 0.0379 & 20 & 150 & 60 & 30 & 30 & 90 & 240 & 30 & 20 & 30 \\
\hline 125 & 0.0119 & 20 & 190 & 80 & 38 & 38 & 112 & 300 & 30 & 20 & 30 \\
\hline 150 & 0.0305 & 20 & 225 & 95 & 45 & 45 & 135 & 360 & 30 & 25 & 30 \\
\hline 200 & 0.0252 & 20 & 300 & 120 & 60 & 60 & 180 & 480 & 30 & 30 & 30 \\
\hline 250 & 0.0101 & 20 & 375 & 150 & 75 & 75 & 160 & 600 & 30 & 30 & 30 \\
\hline 300 & 0.0053 & 20 & 450 & 180 & 90 & 90 & 270 & 720 & 30 & 35 & 30 \\
\hline 350 & 0.0053 & 27 & 525 & 210 & 105 & 105 & 315 & 840 & 32 & 35 & 32 \\
\hline 400 & 0.0016 & 27 & 675 & 240 & 120 & 120 & 360 & 960 & 32 & 40 & 32 \\
\hline 450 & 0.0013 & 28 & 750 & 270 & 135 & 135 & 410 & 1080 & 33 & 45 & 33 \\
\hline 500 & 0.001 & 29 & 900 & 300 & 150 & 150 & 450 & 1220 & 34 & 45 & 34 \\
\hline 600 & 0.001 & 30 & 1050 & 360 & 180 & 180 & 540 & 1440 & 34 & 50 & 35 \\
\hline
\end{tabular}

Table 1a. "Dual Plate Check Valve". Source: Own contribution 
It is a non-return valve used to reduce water hammer phenomenon in large hydraulic applications (oil and gas sector). Table la shows various processes and their times required to manufacture the valve. The sizes manufactured in the FMS are varying from $40 \mathrm{~mm}$ to $600 \mathrm{~mm}$ and their part mix ratios are also indicated.

\subsection{Concentric butterfly valve}

Butterfly valves are designed and manufactured to have optimal mix of structural stability, flow efficiency and effective seating coupled with the advantage of light weight, compact design and ease of operation. These valves offer an ideal as well as economic solution for sea water applications. Table $1 \mathrm{~b}$ shows various processes and their times required to manufacture the valve. The sizes manufactured are varying from $50 \mathrm{~mm}$ to $700 \mathrm{~mm}$.

\begin{tabular}{|c|c|c|c|c|c|c|c|c|c|c|}
\hline \multirow{2}{*}{$\begin{array}{c}\text { Part } \\
\text { Range } \\
(\mathbf{m m})\end{array}$} & \multirow{2}{*}{$\begin{array}{c}\text { Part } \\
\text { Mix }\end{array}$} & \multicolumn{9}{|c|}{ Total Processing Time (Min) } \\
\cline { 3 - 11 } & $\begin{array}{c}\text { Load/ } \\
\text { Unload }\end{array}$ & $\begin{array}{c}\text { Tur- } \\
\text { ning }\end{array}$ & Boring & Drilling & $\begin{array}{c}\text { Rubber } \\
\text { Matching }\end{array}$ & $\begin{array}{c}\text { Lap- } \\
\text { ping }\end{array}$ & Insp & $\begin{array}{c}\text { Pain- } \\
\text { ting }\end{array}$ & $\begin{array}{c}\text { As- } \\
\text { sly }\end{array}$ \\
\hline 50 & 0.2034 & 20 & 60 & 60 & 180 & 20 & 120 & 20 & 15 & 35 \\
\hline 80 & 0.1426 & 20 & 100 & 100 & 250 & 22 & 180 & 21 & 20 & 45 \\
\hline 100 & 0.1108 & 20 & 120 & 120 & 360 & 30 & 240 & 23 & 20 & 60 \\
\hline 150 & 0.213 & 20 & 160 & 160 & 550 & 35 & 360 & 25 & 20 & 60 \\
\hline 200 & 0.0574 & 20 & 240 & 240 & 720 & 40 & 480 & 27 & 30 & 70 \\
\hline 250 & 0.0283 & 22 & 300 & 300 & 900 & 45 & 600 & 30 & 35 & 80 \\
\hline 300 & 0.0119 & 25 & 360 & 360 & 1080 & 50 & 720 & 35 & 35 & 80 \\
\hline 400 & 0.0057 & 28 & 420 & 420 & 1260 & 55 & 840 & 35 & 40 & 80 \\
\hline 450 & 0.0026 & 30 & 480 & 480 & 1440 & 60 & 960 & 40 & 45 & 85 \\
\hline 500 & 0.0027 & 32 & 540 & 540 & 1620 & 65 & 1080 & 45 & 50 & 90 \\
\hline 600 & 0.0029 & 34 & 600 & 600 & 1800 & 70 & 1200 & 50 & 55 & 95 \\
\hline 700 & 0.0016 & 36 & 720 & 720 & 2160 & 75 & 1440 & 55 & 60 & 95 \\
\hline
\end{tabular}

Table 1b. "Concentric Butterfly Valve". Source: Own contribution

\subsection{Double eccentric butterfly valve}

A type of butterfly valve used in general industry, HVAC \& R, building services and public utilities handling fluids such as water, air, gas, mineral oils, dilute acids and alkaline solutions. The process times, sequence of operations, sizes $(80 \mathrm{~mm}$ to $1100 \mathrm{~mm}$ ) and part mix ratios are indicated in Table 1c. 


\begin{tabular}{|c|c|c|c|c|c|c|c|c|c|c|}
\hline \multirow{2}{*}{$\begin{array}{c}\text { Part } \\
\text { Range } \\
\text { (mm) }\end{array}$} & \multirow[b]{2}{*}{$\begin{array}{l}\text { Part } \\
\text { Mix }\end{array}$} & \multicolumn{9}{|c|}{ Total Processing Time (Min) } \\
\hline & & $\begin{array}{l}\text { Load/ } \\
\text { Unload }\end{array}$ & $\begin{array}{l}\text { Tur- } \\
\text { ning }\end{array}$ & $\begin{array}{l}\text { Bo- } \\
\text { ring }\end{array}$ & $\begin{array}{l}\text { Dril- } \\
\text { ling }\end{array}$ & Lapping & $\begin{array}{l}\text { Rubber } \\
\text { Matching }\end{array}$ & $\begin{array}{c}\text { Ins } \\
\text { p. }\end{array}$ & $\begin{array}{l}\text { Pain- } \\
\text { ting }\end{array}$ & $\begin{array}{l}\text { As- } \\
\text { sly }\end{array}$ \\
\hline 80 & 0.0006 & 20 & 96 & 96 & 288 & 192 & 24 & 20 & 72 & 28 \\
\hline 100 & 0.0011 & 20 & 120 & 120 & 360 & 240 & 30 & 20 & 90 & 30 \\
\hline 150 & 0.0013 & 20 & 180 & 180 & 540 & 360 & 32 & 20 & 135 & 32 \\
\hline 200 & 0.0004 & 20 & 240 & 240 & 720 & 480 & 33 & 20 & 180 & 33 \\
\hline 250 & 0.0003 & 21 & 300 & 300 & 900 & 600 & 34 & 21 & 225 & 34 \\
\hline 300 & 0.0006 & 22 & 360 & 360 & 1080 & 720 & 35 & 22 & 270 & 35 \\
\hline 350 & 0.0005 & 23 & 420 & 420 & 1260 & 840 & 36 & 23 & 315 & 36 \\
\hline 700 & 0.0003 & 26 & 840 & 840 & 2520 & 1680 & 38 & 26 & 650 & 38 \\
\hline 900 & 0.0002 & 28 & 1080 & 1080 & 3240 & 2160 & 39 & 28 & 870 & 39 \\
\hline 1100 & 0.0004 & 29 & 1320 & 1320 & 3960 & 2640 & 40 & 29 & 990 & 40 \\
\hline
\end{tabular}

Table 1c. "Double Eccentric Butterfly Valve". Source: Own contribution

\subsection{Triple eccentric butterfly valve}

It is also used in similar applications and specifically suitable for larger installations with the general size varying from $100 \mathrm{~mm}$ to $1000 \mathrm{~mm}$. Other details are illustrated in table $1 d$.

\begin{tabular}{|l|c|c|c|c|c|c|c|c|c|c|}
\hline \multirow{2}{*}{$\begin{array}{c}\text { Part } \\
\text { Range } \\
(\mathbf{m m})\end{array}$} & \multirow{2}{*}{$\begin{array}{c}\text { Part } \\
\text { Mix }\end{array}$} & \multicolumn{9}{|c|}{ Total Processing Time (Min) } \\
\cline { 3 - 12 } & $\begin{array}{c}\text { Load/ } \\
\text { Unload }\end{array}$ & $\begin{array}{c}\text { Tur- } \\
\text { ning }\end{array}$ & $\begin{array}{c}\text { Bo- } \\
\text { ring }\end{array}$ & $\begin{array}{c}\text { Dril- } \\
\text { ling }\end{array}$ & $\begin{array}{c}\text { Lap- } \\
\text { ping }\end{array}$ & $\begin{array}{c}\text { Rubber } \\
\text { Matching }\end{array}$ & Insp & $\begin{array}{c}\text { Pain- } \\
\text { ting }\end{array}$ & $\begin{array}{c}\text { As- } \\
\text { sly }\end{array}$ \\
\hline 100 & 0.0086 & 20 & 120 & 120 & 360 & 240 & 30 & 20 & 90 & 30 \\
\hline 150 & 0.0018 & 21 & 180 & 180 & 540 & 360 & 31 & 21 & 135 & 31 \\
\hline 200 & 0.0013 & 22 & 240 & 240 & 720 & 480 & 32 & 22 & 180 & 32 \\
\hline 250 & 0.0005 & 23 & 300 & 300 & 900 & 600 & 33 & 23 & 225 & 33 \\
\hline 300 & 0.0007 & 24 & 360 & 360 & 1080 & 720 & 34 & 24 & 270 & 34 \\
\hline 500 & 0.0005 & 25 & 600 & 600 & 1800 & 1200 & 35 & 25 & 450 & 35 \\
\hline 600 & 0.0009 & 26 & 720 & 720 & 2160 & 1440 & 36 & 26 & 540 & 36 \\
\hline 800 & 0.0002 & 28 & 960 & 960 & 2880 & 1920 & 38 & 28 & 720 & 38 \\
\hline 1000 & 0.0009 & 30 & 1200 & 1200 & 3600 & 2400 & 40 & 30 & 900 & 40 \\
\hline
\end{tabular}

Table 1d. "Triple Eccentric Butterfly Valve". Source: Own contribution

\section{Performance analysis and modeling of case system}

Literature shows that deterministic study of FMS can reduce the uncertainty involved in the stochastic studies. There are various universal mathematical models available to perform deterministic study and therefore may be utilized. It is felt that better study of an existing system would also help in improving performance and in designing operational parameters of a new FMS. Getting the motivation from the earlier studies it was decided to adopt a well recognized mathematical model 
proposed by Solberg (1981) and further modified by Mejabi (1988). These models have been duly verified and validated in the literature to provide primary estimates of operational parameters such as production rate, workstation load etc. Some assumptions have been considered for the implementation of the model to study the case. These are mentioned below:

1. The study is purely deterministic in nature.

2. This study is not intended to evaluate the dynamic parameters such as build-up of queues, etc.

3. This study is presented by assuming that the output of the system has an upper limit it means the system has inbuilt bottleneck.

4. It is assumed that the product mix flowing through the system is fixed.

5. Throughout the study, operation frequency is unity.

The considered research case involves the assessment and analysis of performance of a flexible manufacturing system at operational level under various parameters. Primary step may be to identify the various such parameters that can affect performance of the system. An overview of the mathematical model used in the research is discussed below:

\subsection{Operational parameters}

\section{Average workload}

To estimate various performance measures, it is required to first calculate the average workload on each work station of FMS which is defined as the mean total time spent at a machining station per part. It will also help to identify the bottleneck in the system if any.

$W L_{i}=\sum_{j} \sum_{k} t_{i j k} f_{i j k} P_{j}$

Where $\mathrm{WL}_{\mathrm{i}}=$ average workload for station $\mathrm{i}$ (Minutes), $\mathrm{t}_{\mathrm{ijk}}=$ Processing time for operation $\mathrm{k}$ in process plan $\mathrm{j}$ at station $\mathrm{i}(\mathrm{Min}), \mathrm{f}_{\mathrm{ijk}}=$ operation frequency for operation $\mathrm{k}$ in part $\mathrm{j}$ at station $\mathrm{i}, \mathrm{p}_{\mathrm{j}}=$ part-mix fraction for part $\mathrm{j}$. The average workload calculated for various workstations of case FMS is summarized in table 2. 


\begin{tabular}{|c|c|c|}
\hline $\begin{array}{c}\text { SI. } \\
\text { No. }\end{array}$ & $\begin{array}{c}\text { Workstations } \\
\text { (Description) }\end{array}$ & $\begin{array}{c}\text { Average Work Load } \\
\text { ( Min) }\end{array}$ \\
\hline $\mathbf{1}$ & Load / Unload Station & 20.85 \\
\hline $\mathbf{2}$ & Turning Center & 152 \\
\hline $\mathbf{3}$ & Welding Station & 16.4 \\
\hline $\mathbf{4}$ & Boring Machine & 138.05 \\
\hline $\mathbf{5}$ & Drilling Station & 324.37 \\
\hline $\mathbf{6}$ & Milling Center & 8.22 \\
\hline $\mathbf{7}$ & Grinding Machine & 24 \\
\hline $\mathbf{8}$ & Lapping Machine & 271.62 \\
\hline $\mathbf{9}$ & Rubber Matching & 48.08 \\
\hline $\mathbf{1 0}$ & Inspection & 24.74 \\
\hline $\mathbf{1 1}$ & Painting Station & 23.51 \\
\hline $\mathbf{1 2}$ & Assembly Station & 48.25 \\
\hline $\mathbf{1 3}$ & Mat. Handling System & 225 \\
\hline & & \\
\hline
\end{tabular}

Table 2. "Average Workload on Workstations". Source: Own contribution

\section{Estimation of bottleneck station}

The case FMS has a bottleneck station which can easily be found by calculating following ratio (Table 3 ).

Bottleneck station $=$ Largest workload to no. of server ratio, i.e. $\frac{W L i}{S i}$

\begin{tabular}{|c|c|c|c|}
\hline $\begin{array}{l}\text { Workstations } \\
\text { (Description) }\end{array}$ & $\begin{array}{c}\text { Average Work Load } \\
\text { (Min) }\end{array}$ & $\begin{array}{c}\text { No. of } \\
\text { Servers }\end{array}$ & $\begin{array}{c}\text { Bottleneck? } \\
\text { (WLi / Si) }\end{array}$ \\
\hline Load / Unload Station & 20.85 & 40 & 0.521288 \\
\hline Turning Center & 152 & 32 & 4.757088 \\
\hline Welding Station & 16.4 & 1 & 16.4013 \\
\hline Boring Machine & 138.05 & 16 & 8.627814 \\
\hline Drilling Station & 324.37 & 4 & $81.09159($ Yes) \\
\hline Milling Center & 8.22 & 2 & 4.10927 \\
\hline Grinding Machine & 24 & 6 & 3.997323 \\
\hline Lapping Machine & 271.62 & 16 & 16.97648 \\
\hline Rubber Matching & 48.08 & 4 & 12.02082 \\
\hline Inspection & 24.74 & 12 & 2.061528 \\
\hline Painting Station & 23.51 & 4 & 5.878682 \\
\hline Assembly Station & 48.25 & 4 & 12.06337 \\
\hline Mat. Handling System & 225 & 16 & 14.0625 \\
\hline
\end{tabular}

Table 3. "Estimation of Bottleneck Station". Source: Own contribution 


\subsection{FMS performance measures}

Various performance evaluation studies can be found in literature and many of them have used performance measures like makespan time (Wadhwa et. al. 2007), lead time, average flow time, (Chan 2006), machine utilization, system utilization etc. Here popular performance measures have been used i.e. production rate of all parts, production rate of each part type, average utilization of workstations, manufacturing lead time and mean waiting time experienced by a part at the stations.

\section{Maximum production rate of all parts}

The maximum production rate ( $p c$ per minute) of all parts is limited by the capacity of bottleneck station and therefore can be calculated as the ratio of $\mathrm{s}^{*}$ (No. of servers at bottleneck station) to WL* (Workload at Bottleneck Station).

$R_{p}^{*}=\frac{s^{*}}{W L^{*}}$

Similarly individual part production rate (of part type j) can be obtained by multiplying $R^{*}{ }_{p}$ by the respective part mix ratios $\left(P_{j}\right)$.

$R_{p j}^{*}=P_{j}\left(R_{p}^{*}\right)=P_{j} \frac{s^{*}}{W L^{*}}$

Implementing the above formula maximum production rate of all parts is found to be $0.74026 \mathrm{Pc} . / \mathrm{hr}$. for our case.

Utilization of each workstation

The mean utilization of each workstation is defined as the amount of time that the servers at the station are working and not idle. The utilization of bottleneck station will be $100 \%$ at $\mathrm{R}^{*}$. considering the above mentioned notations, mean utilization $\mathrm{U}_{\mathrm{i}}$ is represented as (Table 4 )

$U_{i}=\frac{W L_{i}}{s_{i}}\left(R_{P}^{*}\right)=\frac{W L_{i}}{s_{i}} \frac{s^{*}}{W L^{*}}$

Average station utilization $\left(U_{\mathrm{av}}\right)$ can also be found by computing the average value for all stations, including transport system.

$U_{a v}=\frac{\sum_{i=1}^{n+1} U_{i}}{n+1}$ 


\begin{tabular}{|c|c|c|}
\hline \multirow{2}{*}{ Stations } & \multicolumn{2}{|c|}{ Station Utilization } \\
\cline { 2 - 3 } & $\mathbf{( N u m )}$ & $\mathbf{( \% )}$ \\
\hline Load / Unload Station & 0.00643 & 0.6 \\
\hline Turning Center & 0.05869 & 5.869 \\
\hline Welding Station & 0.20235 & 20.235 \\
\hline Boring Machine & 0.10644 & 10.644 \\
\hline Drilling Station & 1.00048 & 100 \\
\hline Milling Center & 0.05069 & 5.069 \\
\hline Grinding Machine & 0.04931 & 4.931 \\
\hline Lapping Machine & 0.20945 & 20.945 \\
\hline Rubber Matching & 0.14831 & 14.831 \\
\hline Inspection & 0.02543 & 2.543 \\
\hline Painting Station & 0.07252 & 7.252 \\
\hline Assembly Station & 0.14883 & 14.883 \\
\hline Mat. Handling System & 0.17349 & 17.349 \\
\hline
\end{tabular}

Table 4. Station Utilization. Source: Own contribution.

\section{Overall FMS utilization}

It is a very useful performance measure and can be calculated using a weighted average, by considering number of servers at each station ( $n$ ) without using transport system. The overall FMS utilization in the case has been calculated as $88.53 \%$.

$U_{\text {Overall }}=\frac{\sum_{i=1}^{n} s_{i} U_{i}}{\sum_{i=1}^{n} s_{i}}$

\section{Manufacturing lead time}

Mejabi (1988) considered a closed queuing network with work in process inventory in FMS and discussed the importance of WIP in FMS operation and estimation of manufacturing lead time (MLT). WIP (N) and MLT are correlated; if N is small, then MLT will be lowest due to the least waiting time. If mean waiting time $\left(T_{w}\right)$ and average workloads at stations are known then WIP (N) and MLT can be calculated using following equations.

$$
\begin{aligned}
& M L T=\sum_{i=1}^{n} W L_{i}+W L_{n+1}+T_{w} \\
& W I P=N=R_{P}(M L T)
\end{aligned}
$$

Manufacturing Lead Time for Existing FMS $=1621.043$ Minutes 
Waiting Time $=295.736$ Minutes

\subsection{Proposed FMS: sizing and other issues}

The existing FMS in the company has been extensively analyzed in section 4.1 and 4.2 based on the data collected through questionnaire distributed to all levels. Various operational and performance parameters have been calculated using the mathematical models available in the literature, it is found that existing FMS is not really running efficiently and therefore the performance of existing system is less than the optimum level. The management of company was keen to invest in achieving more productive system and was desirous to see the designs and recommendations suggested by us. We decided to redesign the existing FMS and therefore proper design procedures were followed and based on the inputs received from the management, the sizing of FMS, layout selection etc. have been done using a mathematical models found in the literature. After the calculation of desired operational parameters, it is decided to assess the performance of proposed system by developing the simulation models. Arena is SIMAN based simulation package which uses various inbuilt modules to model any situation in a graphical user interface. Models have been developed and critical performance parameters such as Average Machine Utilization, Production Rate have been determined. The shift size used for the model run is 480 minutes and the production of parts per shift has been observed also the machine utilization has also been noted from the run for various conditions. A snapshot of Arena model window is also given in figure 1 . The simulation results have shown the huge increase in the system performance.

\section{Sizing of proposed FMS}

Number of servers required at each station to realize a specified production rate can be calculated by the mathematical models suggested by Mejabi (1988) and Solberg (1981). Such estimations are required in the initial stage of FMS design to decide the size (number of stations and servers) of the system. Based on the data provided in table $1 a, 1 b, 1 c$ and $1 d$ regarding the part mix, process sequence, and process times, the number of servers at each station i can be calculated as

$s_{i}=$ minimum integer $\geq R_{P}\left(W L_{i}\right)$

Where $R_{p}=\frac{\text { Annual Target }}{\text { No.of hrs.of FMS operation X Machine Availability }}$ 


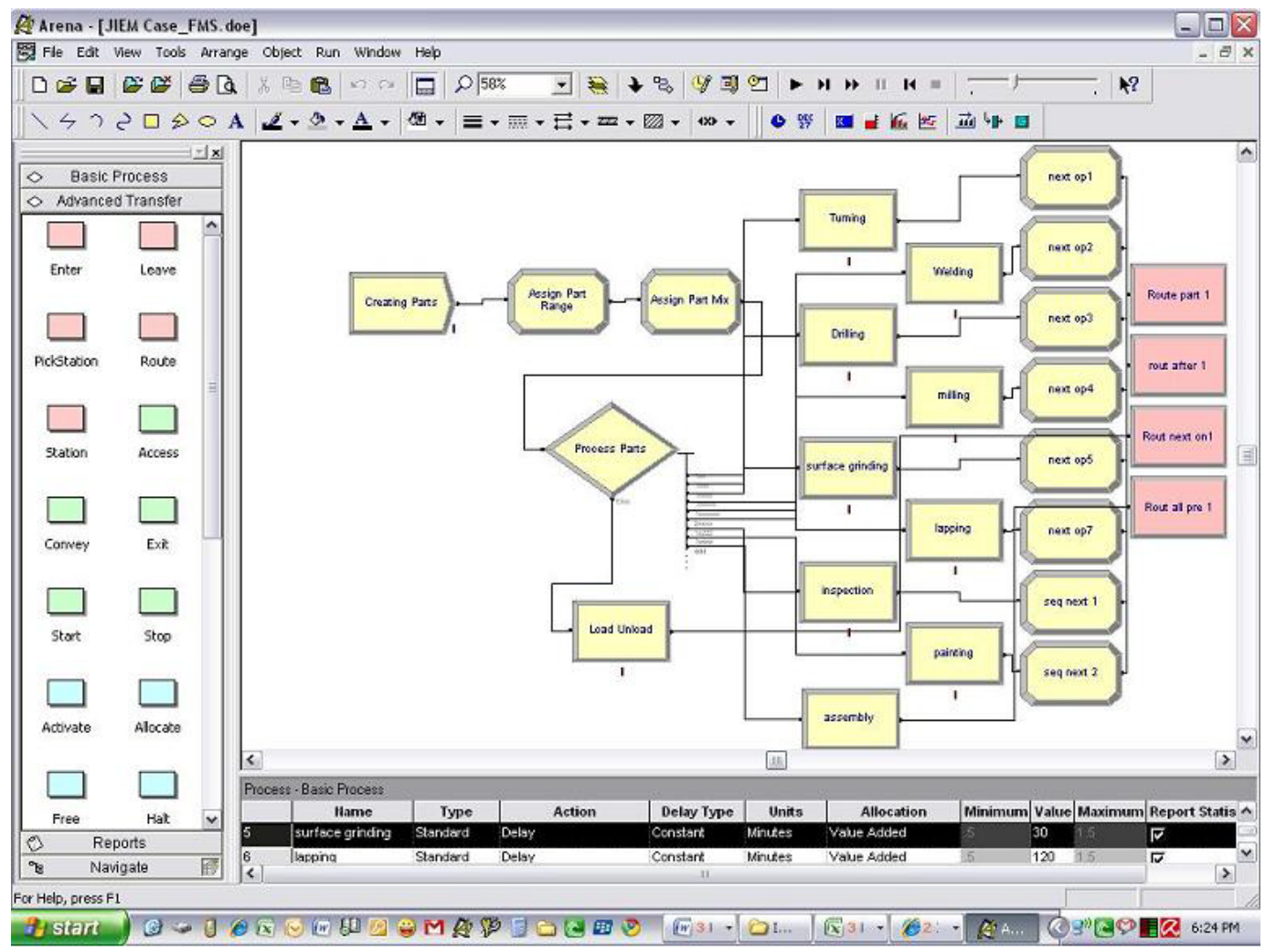

Figure 1. "Arena V.11, Model Snapshot". Source: Own contribution

Table 5 shows the estimated number of servers required for various stations in the proposed FMS.

\begin{tabular}{|c|c|}
\hline \multirow{2}{*}{$\begin{array}{l}\text { Workstations } \\
\text { (Description) }\end{array}$} & No. of Servers \\
\cline { 2 - 2 } Load / Unload Station & 4 \\
\hline (Proposed) \\
\hline Welding Station & 29 \\
\hline Boring Machine & 4 \\
\hline Drilling Station & 27 \\
\hline Milling Center & 62 \\
\hline Grinding Machine & 2 \\
\hline Lapping Machine & 5 \\
\hline Rubber Matching & 10 \\
\hline Inspection & 52 \\
\hline Painting Station & 5 \\
\hline Assembly Station & 5 \\
\hline Mat. Handling System & 10 \\
\hline
\end{tabular}

Table 5. "No. of Servers in Proposed FMS". Source: Own contribution 


\section{Layout and flow diagram of proposed FMS}

The material handling system generally is a key factor in determining the type of layout to be used in any FMS. In literature, number of popular layout types have been highlighted, some of them are in-line layout, loop layout, ladder layout, open field layout etc. After the detailed study about the plant including space availability, number of operators working etc, the loop layout was considered for the implementation for the new FMS. The key rationales are given below:

a. Loop layout is suitable for mid variety and mid volume range of the case company.

b. Loop layout consists of secondary handling system which is required to provide desirable flexibility of routing.

c. It has reduced material transfer time.

d. In the case company, the manpower will be greatly reduced as workers are required only at load/unload station.

e. Traffic control is easy to implement in loop layout.

The layout configuration and flow diagram for loop layout are given in figure 2 and 3 respectively.

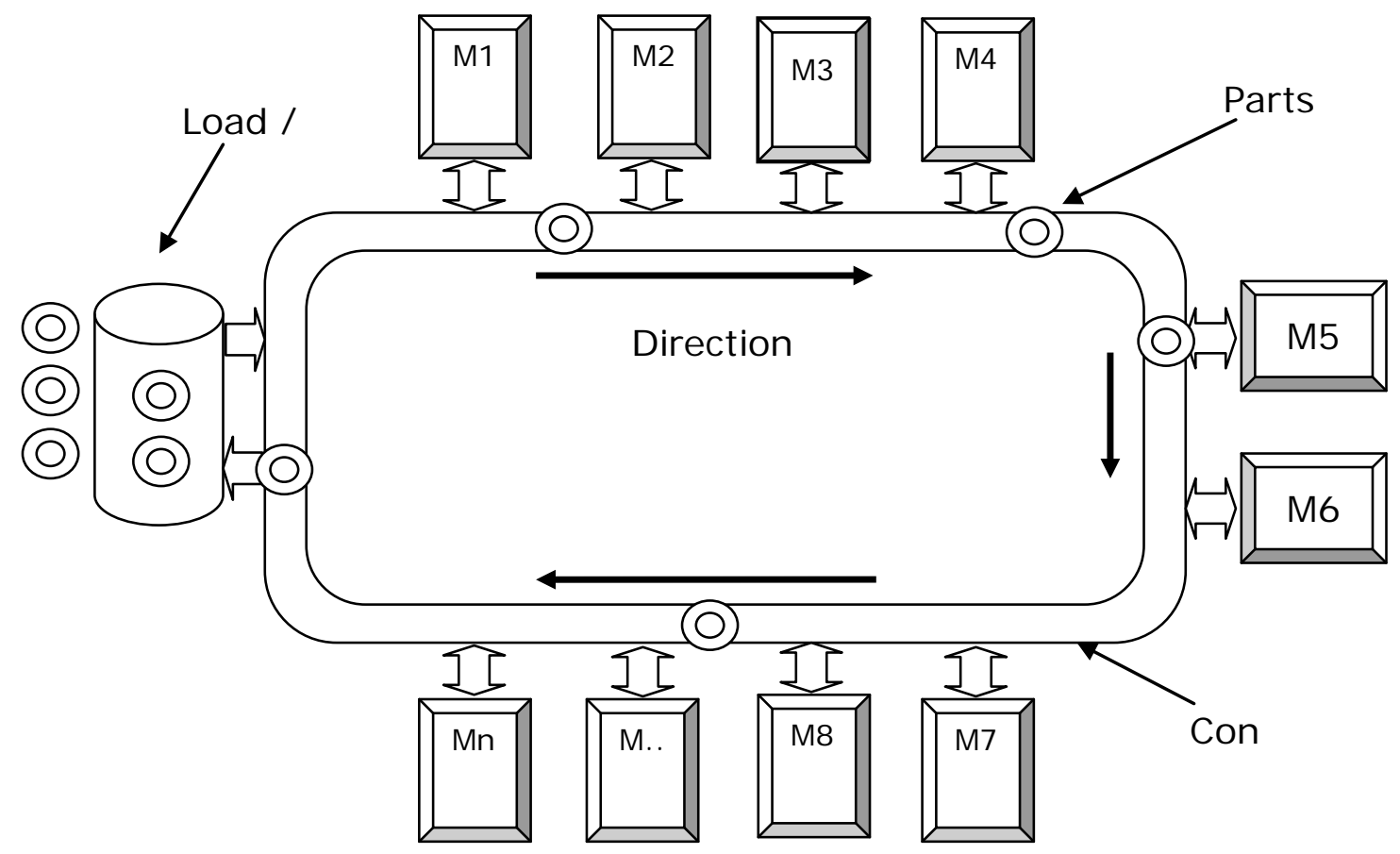

Figure 2. "Loop Layout configuration". Source: Own contribution 


\section{Calculation of performance measures of proposed FMS}

Initial sizing calculations in previous section are helpful for the estimation of performance measures for the proposed FMS. Same mathematical model described in section 4.1 and 4.2 can be exploited to evaluate crucial performance parameters like increased station utilization, maximum production rate, overall system utilization of proposed FMS etc. The increase station utilization and various performance parameters of proposed FMS have been shown in Table 6 and 7 respectively.

\begin{tabular}{|c|c|}
\hline Stations & $\begin{array}{c}\text { Utilization } \\
\mathbf{( \% ) ~}\end{array}$ \\
\hline Load / Unload Station & 98.7 \\
\hline Turning Center & 99.4 \\
\hline Welding Station & 77.6 \\
\hline Boring Machine & 96.8 \\
\hline Drilling Station & 99 \\
\hline Milling Center & 77.8 \\
\hline Grinding Machine & 90.8 \\
\hline Lapping Machine & 91 \\
\hline Rubber Matching & 98.9 \\
\hline Inspection & 93.7 \\
\hline Painting Station & 89 \\
\hline Assembly Station & 91.3 \\
\hline Mat. Handling System & 99 \\
\hline
\end{tabular}

Table 6. "Increased Station Utilization in proposed FMS". Source: Own contribution

\begin{tabular}{|c|c|c|}
\hline SI. No. & Performance Parameters & Estimated Value \\
\hline 1 & Maximum Production Rate (Pc./Hr) & 11.4306 \\
\hline 2 & Most Utilized Station & $99.40 \%$ \\
\hline 3 & New Bottleneck Station & Turning Station \\
\hline 4 & Overall Utilization of System (\%) & $99.99 \%$ \\
\hline
\end{tabular}

Table 7. "Performance Parameters of proposed FMS". Source: Own contribution 


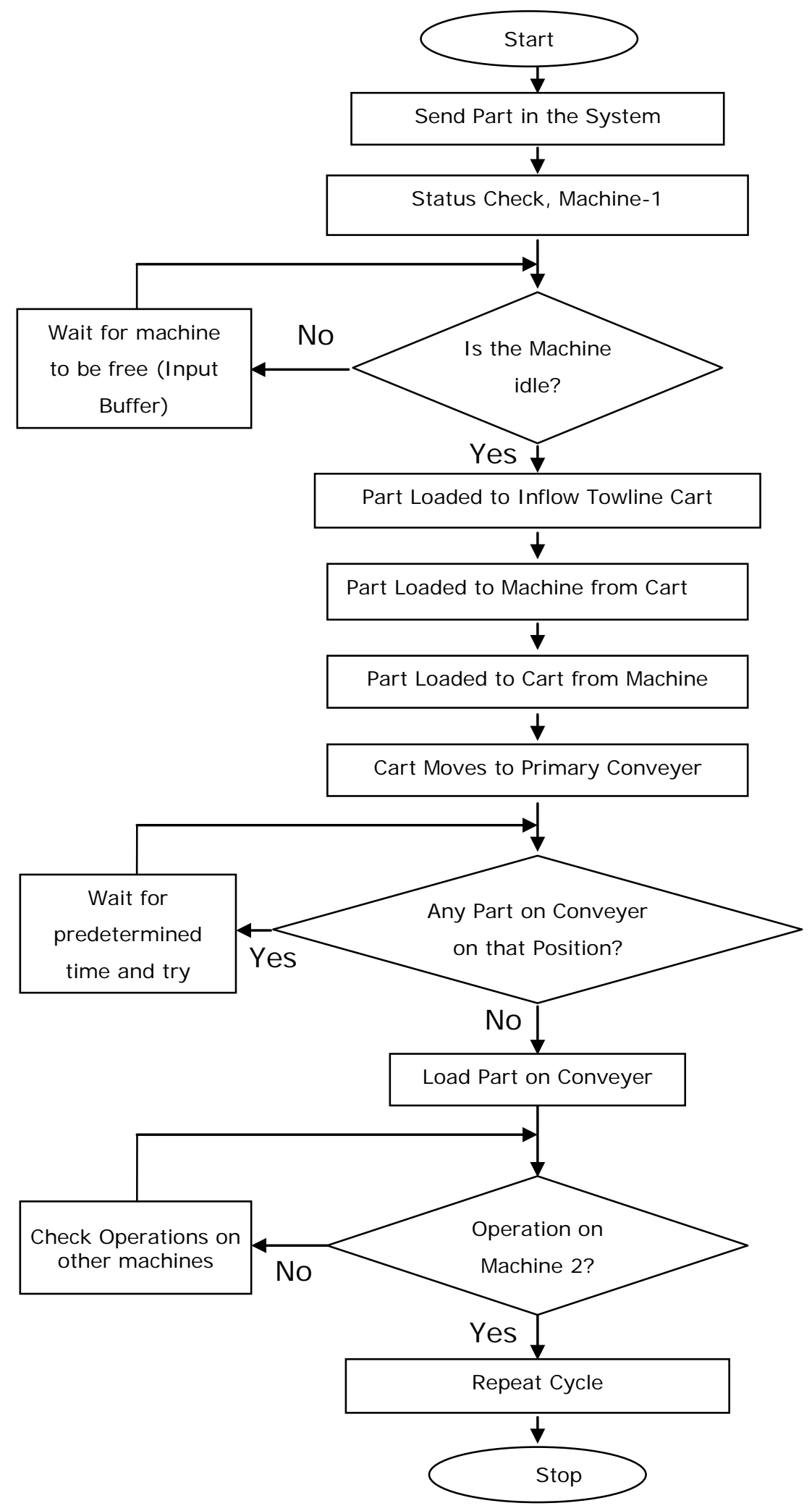

Figure 3. "Flow diagram for Loop Layout". Source: Own contribution 


\section{Simulation modeling of proposed FMS}

Simulation modeling is a universal paradigm for analyzing complex systems and often used to develop a simplified representation of a complex system with the objective of providing predictions of the system's performance measures. Number of commercial languages and packages are available for simulation modeling. Hlupic and Paul (1995) critically assessed the WITNESS, Arena, SIMFACTORY, ProModel, and XCELL packages. O'Keefe and Haddock (1991) described the various advantages of data driven generic simulators for flexible manufacturing systems. Ali and Wadhwa (2005) developed Arena based simulators to improve the performance of FMS. Previous sections evaluate various parameters pertaining to the proposed FMS using the mathematical models suggested in literature. In view of the complexity of the proposed system it was decided to develop the simulation models for the system so that the behavior and key performance measures can be predicted and verified simultaneously. The use of software package ARENA has been found extensively in the literature for the performance modeling of complex systems; therefore ARENA Version 11.0 professional was used to model the system. The graphical model of the proposed FMS has been prepared and subsequently the behavior of system was recorded for various real life situations. Various performance parameters were also estimated during the simulation run and it is found that the mathematical results are in concurrence with simulation results with the deviation ranging from 4 to $9.3 \%$ in various parameters.

\section{Results and discussion}

The performance analysis of existing as well as proposed FMS has been presented in the previous section. The summary of case calculations (Average workload, system utilizations, bottleneck, number of servers etc) has been presented in table 2, 3 4, 5, 6 and 7. I nitially operational parameter like maximum workload on each workstation has been calculated and it is found that the average workload on drilling station is 324.37 (minutes) with the total number of servers 4 , on this basis the ratio of average workload to server comes out to be 81.08 (maximum in all stations) which clearly indicates that the drilling station is creating a bottleneck in the processing of parts. Mathematical model explains that the performance of any system will mainly depend on the performance of the bottleneck station, therefore any performance improvement strategy can be thought either by shifting this 
bottleneck to some other convenient station or by neutralizing the effect of bottleneck. This finding has been utilized while designing the proposed system and the bottleneck has been shifted to turning station with the adequate number of servers to cater the workload requirement. Another important performance measure of any FMS is the mean utilization of workstations. For the existing system, the utilizations of stations have been calculated and summarized in table 4 and it observed that few stations are underutilized (like load/unload, inspection, turning) whereas some are highly loaded (100\% utilized like drilling), this kind of load distribution was creating a chaos in the system resulting in less overall system performance. This problem was considered as a major barrier in achieving the optimum performance level of the system and therefore has been addressed while the sizing of proposed FMS. The workload requirement has been studied carefully and by the use of mathematical model described in section 4.3, calculations for the optimum number of servers for each workstation have been done and presented in table 5. A comparison of number of servers and station utilizations for the old and proposed system is shown in figure 4 and figure 5 respectively.

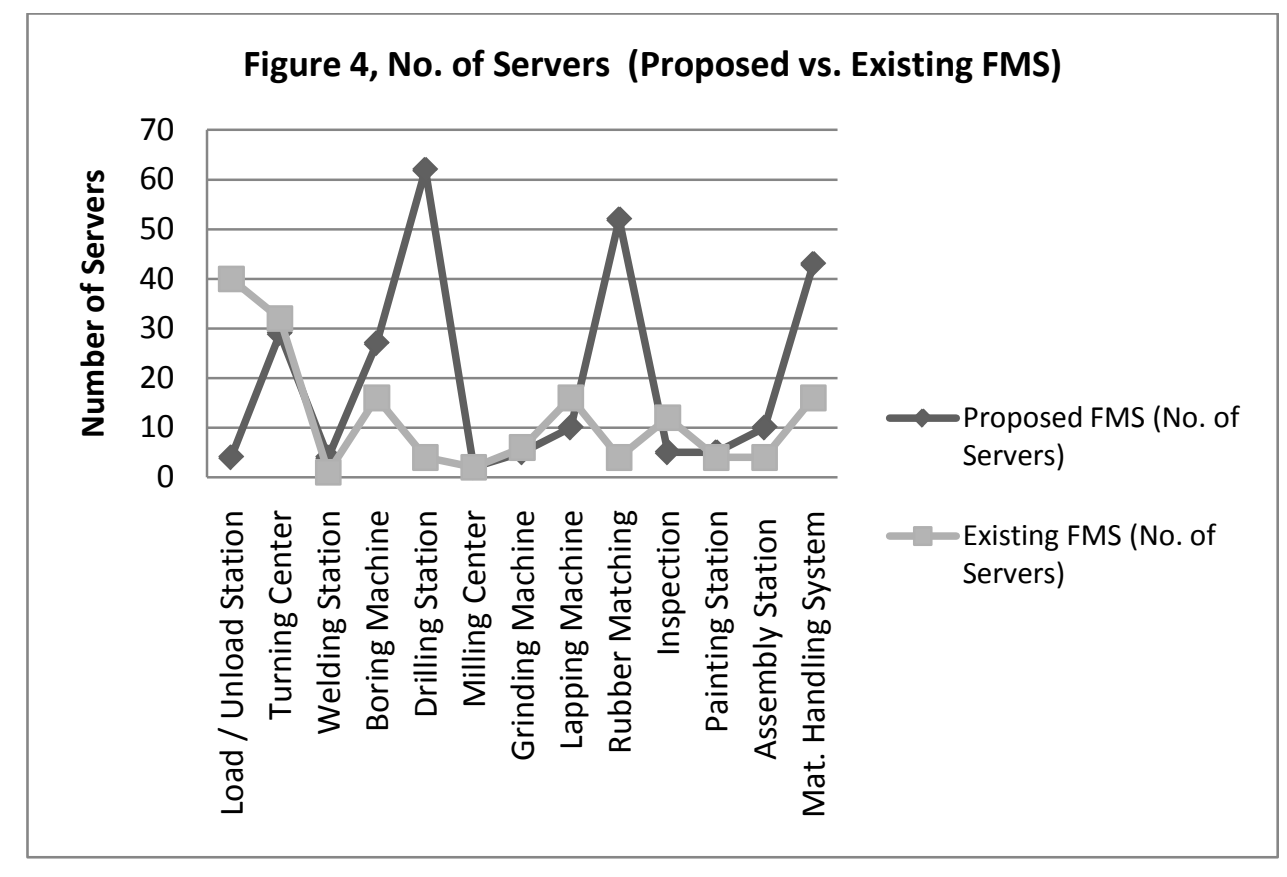

Figure 4. "No. of Servers (Proposed vs. Existing)". Source: Own contribution. 


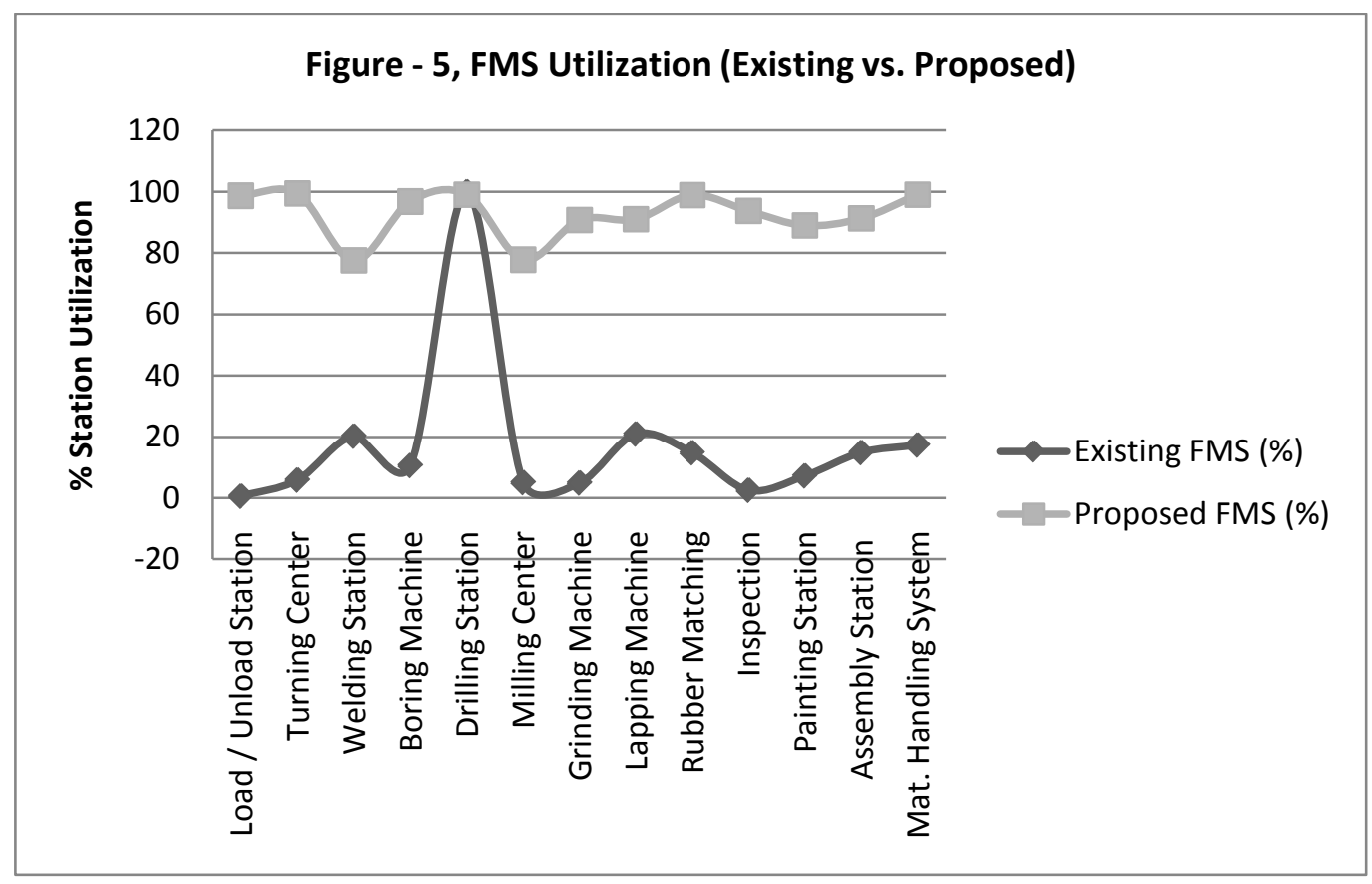

Figure 5. "FMS Utilization (Proposed vs. Existing)". Source: Own contribution

The study of existing FMS reveals that due to the problems encountered as above, the maximum production rate of all parts was very less. The performance improvement can be seen from the calculations of maximum production rate of all parts for the proposed system and the difference is huge. Similarly other parameters like overall FMS utilization, average production rate etc. have been seen improving for the proposed system. A comparison chart of all these parameters showing the performance improvement (verified with simulation) is presented in table 8.

\begin{tabular}{|c|c|c|c|}
\hline SI. No. & Performance Parameters & Proposed & Existing \\
\hline 1 & Maximum Production Rate (Pcs./Hr) & 11.4306 & 0.74026 \\
\hline 2 & Most Utilized Station & $99.40 \%$ & $99.99 \%$ \\
\hline 3 & New Bottleneck Station & Turning Station & Drilling Station \\
\hline 4 & Overall Utilization of System (\%) & $99.99 \%$ & $88.53 \%$ \\
\hline
\end{tabular}

Table 8. "Comparison Chart of Performance Parameters of FMS (Proposed vs. Existing)". Source: Own contribution.

\section{Conclusion}

In this paper, a case study of a manufacturing firm is presented on the basis of the mathematical model given by Solberg (1981) and Mejabi (1988). The objective of 
the study was to analyze the existing system and prepare a plan to improve the performance of system. Various techniques like quantitative modeling, simulation modeling have been utilized to achieve the objectives. Initially various operational and performance parameters were calculated then the new FMS has been proposed with the optimum number of servers. It is discovered that the maximum workload per server in the existing system is in drilling station which is also established by the fact that the machine utilization of this station is $99.99 \%$. These results reveal that the drilling station is a bottleneck station. Since this station is crucial for the processing of all part types, It is suggested that the bottleneck should be shifted from this station to some other less important process in the proposed FMS. The system utilization was another important issue which has been addressed in this study, The overall system utilization of existing system was $88.53 \%$ and the proposed FMS has been designed to deliver $99.99 \%$ overall utilization with appropriate loading on all stations. It is also found that in existing system the resources were not properly utilized as some stations like loading/unloading, inspection, grinding, milling and turning were underutilized ranging from $0.6 \%$ to $5.8 \%$, and therefore it was mandatory to adequately distribute the workload on all stations. The proposed FMS has increased the number of servers from 157 to 258 (about $64 \%$ increase) which has contributed in the increase of the maximum production rate from 0.740 to 11.43 pc per hour ( 14 times the existing production) and an increase in overall utilization of resources ( $88 \%$ to $99.99 \%$ ). This justifies the return on investment as a huge increase in productivity and overall utilization is observed on just $64 \%$ rise in no. of servers.

The findings of this study have important managerial significance. The management can obtain better insight and guidelines for determining various decisions relating to process and operations improvement and investment in new facility. These results and findings have also been forwarded to the company management for further implementation analysis purpose. Other operating conditions of system like system layout, material handling systems etc. can also be considered in future and the effect of these parameters can also be studied using our simulation model. In future it is also intended to conduct various simulation experiments so that system would be robust enough to handle all situation and dynamic market conditions. 


\section{Appendices}

\section{Product Details}

\section{QUESTI ONAI RE}

Q1) What types of products are manufactured in the production units?

Q2) What are the different components that go into making the products?

Q3) What is the processing time of all the operations involved in the manufacturing of each product?

Q4) What is the facility provided for material handling and part transport in the units? Is it manual or automated? State clearly the type if it is automated.

Q5) In case the material handling system is entirely manual, then how many workers are involved in the same?

Q6) How is loading/unloading done on the machine, manually or there is automated station provided?

Q7) How many machines are provided in production units for manufacturing each product?

Q8) What is the level of organization in the production plant?

Q9) What is the idle time on various machines employed in the production of the each product?

Q10) What is the lead time in production?

\section{Production Facility Design}

Q1) What is the total area occupied by inventories?

Q2) Is there any plant layout followed if yes then state the type.

Q3) What is the level of automation in production units?

Q4) Are the production units flexible enough to accommodate changes in?
a) Plant layout
b) Product variety
c) Production volume
d) Machine breakdown
e) Miscellaneous 


\section{Financial Parameters}

Q1) What is the total projected cost of the new production facility?

Q2) What is the allocated cost of the following?
a) Machines and Equipment
b) Manpower
c) Inventory
d) Electricity
e) Labor training
f) Miscellaneous

Q3) Would you be interested in automating the new facility at additional cost?
O YES
o NO

Q4) Is there any process that you will prioritize for automation, if yes then name the process(s)?

Q5) What is the total cost that the company is ready to bear for implementing flexible manufacturing system (F.M.S.) in the upcoming unit?

\section{LIST OF NOTATI ONS}

$P_{j}: \quad$ Part mix fraction for part $j$

$f_{i j k}$ : Operation frequency for operation $k$ in part $j$ at station $i$

$t_{i j k}$ : Processing time for operation $k$ in process plan $j$ at station $i$

j: $\quad$ Part

k: Operation

i: Station

$\mathrm{WL}_{\mathrm{i}}$ : $\quad$ Average workload for station $\mathrm{i}$ in minutes

$\mathrm{s}_{\mathrm{i}}$ : Number of servers

S*: no. servers at bottleneck station

WL*: Workload at bottleneck station

Rp*: Maximum Production Rate

$\mathrm{U}_{\mathrm{i}}$ : Utilization of each workstation 
$\mathrm{U}_{\mathrm{av}}: \quad$ Overall FMS utilization

MLT: Manufacturing lead time

WIP: Work in Process

$\mathrm{T}_{\mathrm{w}}$ : $\quad$ Mean Waiting time

$\mathrm{R}_{\mathrm{p}}$ : Production Rate

\begin{tabular}{|c|c|c|c|c|c|}
\hline \multicolumn{6}{|c|}{ Sample calculation of workload for load/ unload station } \\
\hline Part Name & $\begin{array}{c}\text { Part } \\
\text { Range }\end{array}$ & $\begin{array}{c}\text { Part Mix } \\
\left(\mathbf{P}_{\mathrm{j}}\right)\end{array}$ & $\begin{array}{l}\text { Frequency } \\
\left(f_{i j k}\right)\end{array}$ & $\begin{array}{c}\text { Load/ unload Time } \\
\left(t_{i j k}\right)\end{array}$ & $\begin{array}{c}W_{L_{i}} \\
\text { (Minutes) }\end{array}$ \\
\hline \multirow{15}{*}{$\begin{array}{c}\text { Dual Plat } \\
\text { Check } \\
\text { Valve }\end{array}$} & 40 & 0.00038 & 1 & 20 & 0.0076 \\
\hline & 50 & 0.0247 & 1 & 20 & 0.494 \\
\hline & 65 & 0.02267 & 1 & 20 & 0.4534 \\
\hline & 80 & 0.03 & 1 & 20 & 0.6 \\
\hline & 100 & 0.03787 & 1 & 20 & 0.7574 \\
\hline & 125 & 0.01193 & 1 & 20 & 0.2386 \\
\hline & 150 & 0.0305 & 1 & 20 & 0.61 \\
\hline & 200 & 0.0252 & 1 & 20 & 0.504 \\
\hline & 250 & 0.0101 & 1 & 20 & 0.202 \\
\hline & 300 & 0.00528 & 1 & 20 & 0.1056 \\
\hline & 350 & 0.00528 & 1 & 27 & 0.14256 \\
\hline & 400 & 0.0016 & 1 & 27 & 0.0432 \\
\hline & 450 & 0.00128 & 1 & 28 & 0.03584 \\
\hline & 500 & 0.00103 & 1 & 29 & 0.02987 \\
\hline & 600 & 0.00097 & 1 & 30 & 0.0291 \\
\hline \multirow{12}{*}{$\begin{array}{c}\text { Concentric } \\
\text { Butterfly } \\
\text { Valve }\end{array}$} & 50 & 0.2034 & 1 & 20 & 4.068 \\
\hline & 80 & 0.1426 & 1 & 20 & 2.852 \\
\hline & 100 & 0.11078 & 1 & 20 & 2.2156 \\
\hline & 150 & 0.213 & 1 & 20 & 4.26 \\
\hline & 200 & 0.0574 & 1 & 20 & 1.148 \\
\hline & 250 & 0.0283 & 1 & 22 & 0.6226 \\
\hline & 300 & 0.01186 & 1 & 25 & 0.2965 \\
\hline & 400 & 0.00568 & 1 & 28 & 0.15904 \\
\hline & 450 & 0.00257 & 1 & 30 & 0.0771 \\
\hline & 500 & 0.00274 & 1 & 32 & 0.08768 \\
\hline & 600 & 0.00288 & 1 & 34 & 0.09792 \\
\hline & 700 & 0.00161 & 1 & 36 & 0.05796 \\
\hline
\end{tabular}




\begin{tabular}{|c|c|c|c|c|c|}
\hline \multicolumn{6}{|c|}{ Sample calculation of workload for load/ unload station } \\
\hline Part Name & $\begin{array}{c}\text { Part } \\
\text { Range }\end{array}$ & $\begin{array}{c}\text { Part Mix } \\
\left(\mathbf{P}_{\mathrm{i}}\right)\end{array}$ & $\begin{array}{c}\text { Frequency } \\
\left(f_{i j k}\right)\end{array}$ & $\begin{array}{c}\text { Load/ unload Time } \\
\left(t_{i j k}\right)\end{array}$ & $\begin{array}{c}\mathbf{W L}_{\mathrm{i}} \\
\text { (Minutes) }\end{array}$ \\
\hline \multirow{10}{*}{$\begin{array}{c}\text { Double } \\
\text { Eccentric } \\
\text { Butterfly } \\
\text { Valve }\end{array}$} & 80 & 0.00063 & 1 & 20 & 0.0126 \\
\hline & 100 & 0.00113 & 1 & 20 & 0.0226 \\
\hline & 150 & 0.0013 & 1 & 20 & 0.026 \\
\hline & 200 & 0.00037 & 1 & 20 & 0.0074 \\
\hline & 250 & 0.00025 & 1 & 21 & 0.00525 \\
\hline & 300 & 0.00056 & 1 & 22 & 0.01232 \\
\hline & 350 & 0.00051 & 1 & 23 & 0.01173 \\
\hline & 700 & 0.00033 & 1 & 26 & 0.00858 \\
\hline & 900 & 0.00024 & 1 & 28 & 0.00672 \\
\hline & 1100 & 0.00038 & 1 & 29 & 0.01102 \\
\hline \multirow{9}{*}{$\begin{array}{c}\text { Triple } \\
\text { Eccentric } \\
\text { Butterfly } \\
\text { Valve }\end{array}$} & 100 & 0.00857 & 1 & 20 & 0.1714 \\
\hline & 150 & 0.00178 & 1 & 21 & 0.03738 \\
\hline & 200 & 0.00131 & 1 & 22 & 0.02882 \\
\hline & 250 & 0.00054 & 1 & 23 & 0.01242 \\
\hline & 300 & 0.00067 & 1 & 24 & 0.01608 \\
\hline & 500 & 0.00051 & 1 & 25 & 0.01275 \\
\hline & 600 & 0.0009 & 1 & 26 & 0.0234 \\
\hline & 800 & 0.000158 & 1 & 28 & 0.004424 \\
\hline & 1000 & 0.0009 & 1 & 30 & 0.027 \\
\hline & & & & $\Sigma W L_{i}$ & 20.8534 \\
\hline
\end{tabular}

\section{References}

Ali, M., \& Wadhwa, S. (2005). Performance analysis of partial flexible manufacturing systems. Global J ournal of Flexible Systems Mgt, 6(1), 9-19.

Barad, M., \& Sipper, D. (1988). Flexibility in manufacturing systems: definitions and Petri net modeling. International Journal Production Resesearch, 26, 237248. doi: $10.1080 / 00207548808947856$

Browne, J., Dubois, D., Rathmill, K., Sethi, S. P., \& Stecke, K. E. (1984). Classification of flexible manufacturing systems. The FMS Magazine, 114.

Buitenhek, R., Baynat, B., \& Dallery, Y. (2002). Prod capacity of flexible mfg. systems with fixed prod ratios. International Journal Flexible Manufacturing Systems, 4(3), 203-226. 
Chan, F. T. S. (2003). Effects of dispatching and routing decisions on the performance of a flexible $\mathrm{mfg}$ systems. International Journal Manufacturing Technology, 21, 328-338. doi:10.1007/s001700300038

Chan, F. T. S., Bhagwat, R., \& Wadhwa, S., (2006). Increase in flex: prod. or counterprod? A study on FMS. International Journal of Production Research, 44(7), 1431-1445.

doi: $10.1080 / 00207540500398959$

Chan, F. T. S., Chan, H. K., (2004). Analysis of dynamic control strategies of an FMS under different scenarios. Robotics and Computers International Manufacturing, 20, 423-437. doi:10.1016/j.rcim.2004.03.005

Chan, F. T. S., Wadhwa. S., Bibhushan (2007). Inventory performance of some supply chain inventory policies under impulse demands. International Journal of Production Research, Manuscript ID: TPRS-2007-IJPR-0111.

Correa, H. L., \& Slack, N. (1996). Framework to analyze flexibility and unplanned change in mfg systems. Computer-Integrated Manufacturing Systems, 9, 57-64. doi: 10.1016/0951-5240(95)00038-0

Hlupic, V., \& Paul, R. J. A. (1995). A critical evaluation of four manufacturing simulators. Int J ournal of Production Research, 33(10), 2757-2766. doi: $10.1080 / 00207549508904843$

Jang, S. Y., Park, J., \& Park, N. (1996). An integrated decision support system for FMS prod planning and scheduling problems. International Journal Advance Manufacturing Technology, 11, 101-110.

doi: $10.1007 / B F 01341558$

Kumar, S., \& Sridharan, R. (2007). Simulation modeling and analysis of tool sharing and part scheduling decisions in single-stage multi-machine flexible manufacturing systems. Robotics and Computer-Integrated Manufacturing, 23, 361-370. doi: 10.1016/j.rcim.2006.02.013

Kusiak, A. (1985). The part families problem in flexible manufacturing systems. Annual Operation Research, 3, 279-300. doi: 10.1007/BF02023710 
Mac Carthy, L. (1993). A new classification scheme for flexible manufacturing systems. International J ournal of Production Research, 31, 299-309. doi: $10.1080 / 00207549308956726$

Mejabi, O. (1988). Modeling in flexible manufacturing systems design. Ph.D. Dissertation, Lehigh University, Bethlehem, Pennsylvania, USA.

Montazeri, M., \& Van Wassenhove, L. N. (1990). Analysis of scheduling rules for an FMS. International Journal of Production Research, 28(4), 785-802. doi: $10.1080 / 00207549008942754$

O'Keefe, R. M., \& Haddock, J. (1991). Data-driven generic simulators for FMSs. International Journal of Production Research, 29(9), 1795-1810. doi: $10.1080 / 00207549108948050$

Ramasesh, R. V., \& Jayakumar, M. D. (1991). Measurement of mfg flexibility: a value based approach. Journal of Operational Management, 10(4), 446-468. doi: 10.1016/0272-6963(91)90005-I

Shnits, B., Rubinovittz, J., \& Sinreich, D. (2004). Multi-criteria dynamic scheduling methodology for controlling a FMS. International Journal of Production Research., 42, 3457-3472. doi: 10.1080/00207540410001699444

Solberg, J. J. (1981). Capacity planning with a stochastic work flow model. AlIE Transaction, 13(2), 116-122. doi: 10.1080/05695558108974543

Stecke, K. E., \& Solberg, J., J. (1981). Loading and control policies for a flexible manufacturing system. International J ournal of Production Research, 19(5), 481490. doi: $10.1080 / 00207548108956679$

Tunali, S. (1997). Evaluation of alternate routing policies in scheduling a job-shop type FMS. Comp Ind Eng, 32(2), 243-325. doi:10.1016/S0360-8352(96)00306-3

Upton, D. (1994). The management of manufacturing flexibility. California Management Review, 36(2), 72-89.

Wadhwa, S., \& Browne, J. (1989). Modeling FMS with Petri Nets. International Journal of flexible Manufacturing Systems, 1, 255-280. doi: 10.1007/BF00235268 
Wadhwa, S., Rao, K. S., \& Chan, F. T. S. (2005). Flexibility-enabled lead-time reduction in flexible Sys. International Journal of Production Research, 43(15), 3131-3163. doi: 10.1080/00207540500076530

Weber, D. M., \& Moodie, C. L. (1989). An intelligent information system for an automated, Integrated Mfg System. Journal of Manufacturing Systems, 8, 99113. doi: $10.1016 / 0278-6125(89) 90029-0$

Womack, J. P., Jones, D. T., \& Roos, D. (1990). The machine that changed the world. New York: Rawson Associates, 11-15.

(C) Journal of Industrial Engineering and Management, 2010 (www.jiem.org)

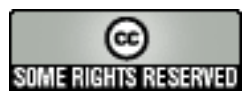

Article's contents are provided on a Attribution-Non Commercial 3.0 Creative commons license. Readers are allowed to copy, distribute and communicate article's contents, provided the author's and Journal of Industrial Engineering and Management's names are included. It must not be used for commercial purposes. To see the complete license contents, please visit http://creativecommons.org/licenses/by-nc/3.0/. 